\title{
Collisional orogeny for the Late Cretaceous-Paleogene Laramide event
}

Robert S. Hildebrand, 1401 N. Camino de Juan, Tucson, AZ 85745 \& Joseph B. Whalen, Geological Survey of Canada, 601 Booth St., Ottawa, ON K1A 0E8

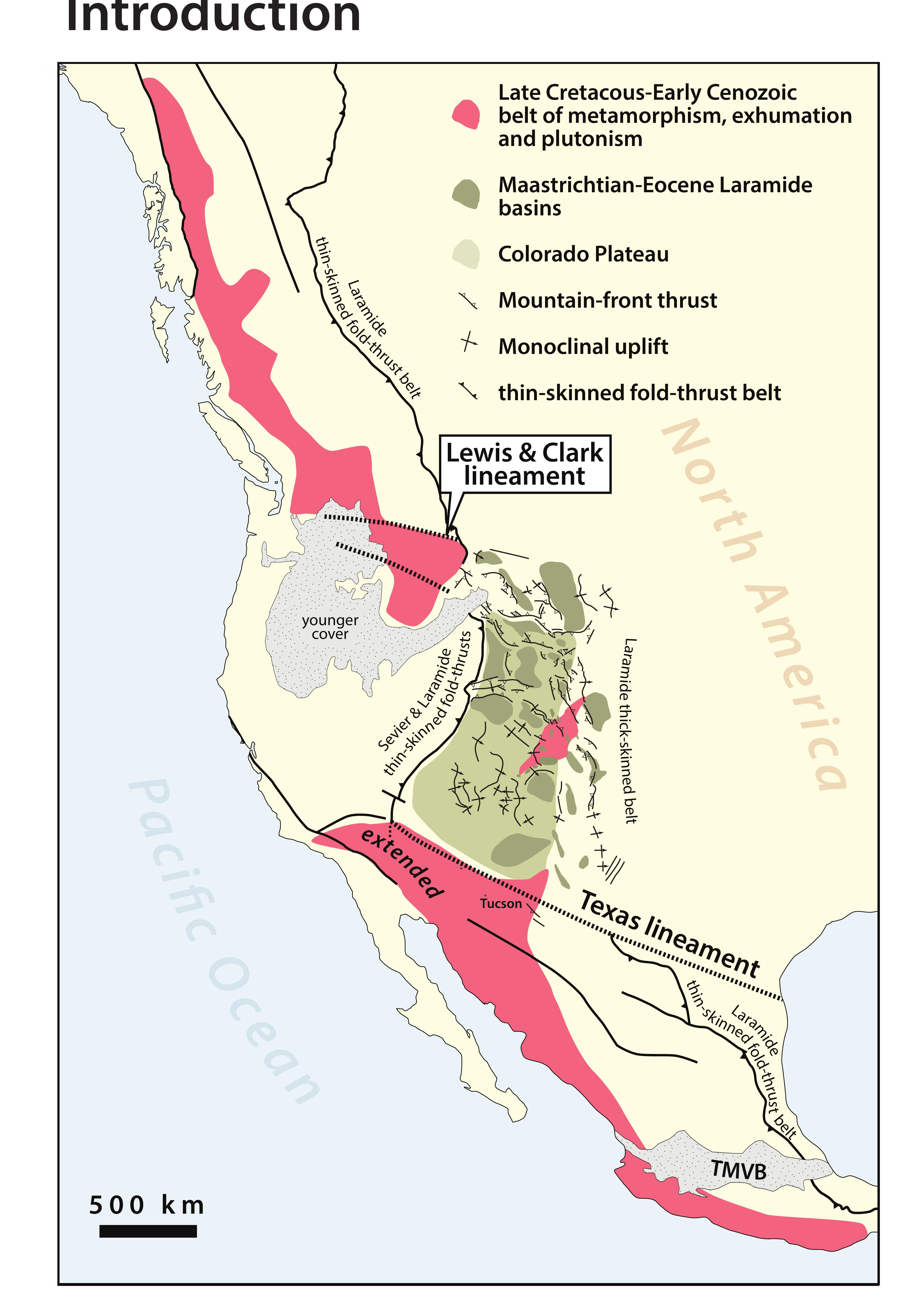

The Laramide event is a Late Cretaceousearly Cenozoic deformational event that appears to have affected rocks from Tierra del Fuego to Alaska (Hildebrand and Whalen, 2014a). Deformation was both

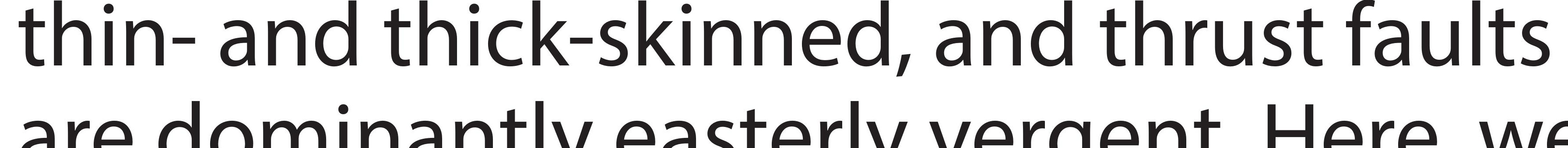
focus on the North American sector, which not only includes thrust and strike-slip faults within both the Cordilleran foldand-thrust belt and Rocky Mountain foreland, but also an exhumed metamorphic hinterland riddled with largely postdeformational plutons. We first address the traditional Laramide thick-skinned deformation within the Rocky Mountain foreland as most geologists consider this the essence of the Laramide event, or orogeny.

\section{Laramide thick-skin deformation}

The Rocky Mountain foreland of west-central North America contains a number of spectacular mountain ranges and adjacent syntectonic
basins filled by alluvial and lacustrine deposits. basins filled by alluvial and lacustrine deposits. crystalline massifs hundreds of kilometers long in the Rocky Mountains to enormous monoclinal flexures on the Colorado Plateau. The uplifts trend north-south, northwest-southeast, or east-west. The deformation is thick-skinned, as
it involved cratonic basement and commonly referred to as "Laramide style".

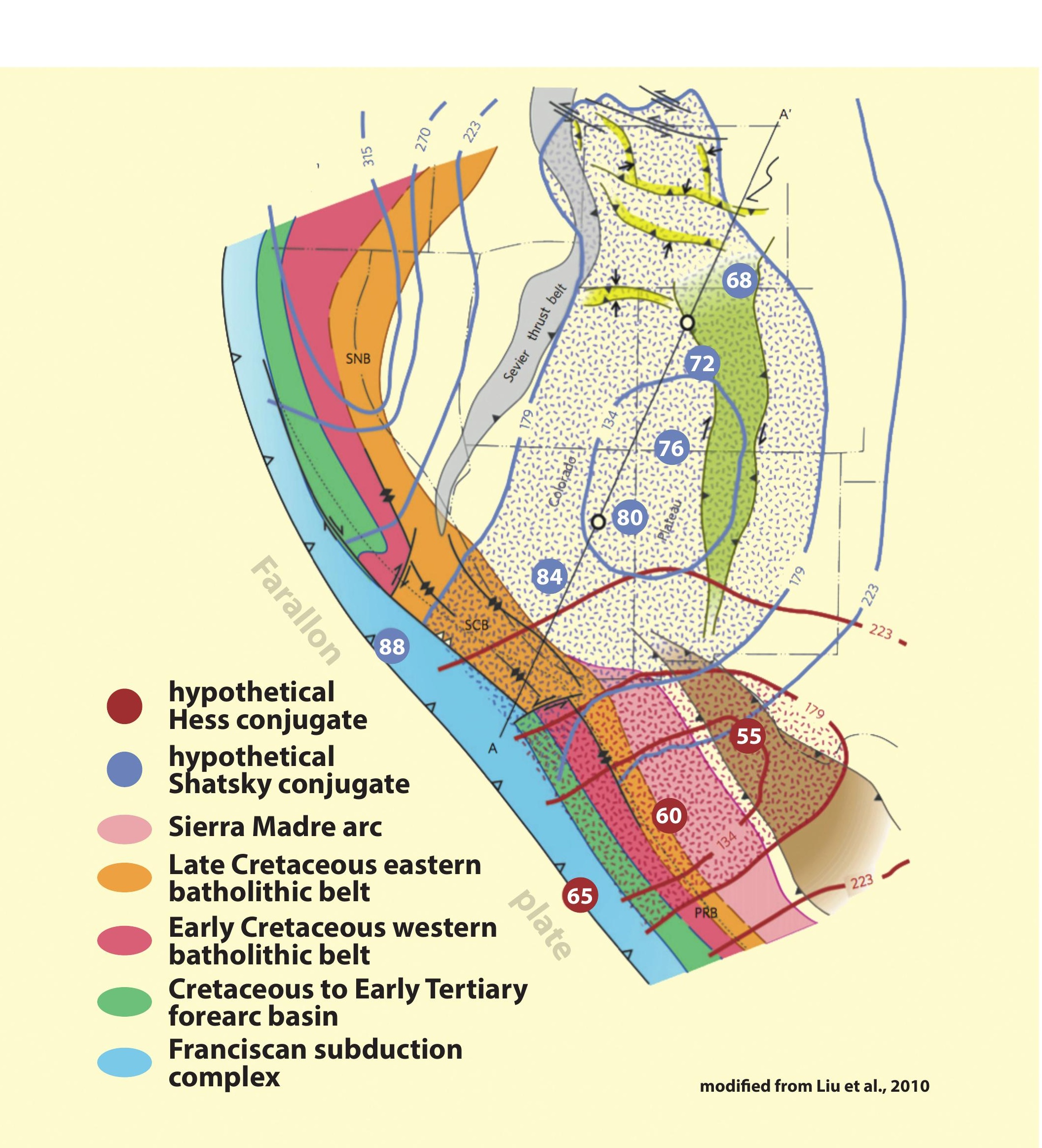

The standard model oday attempts to explain the lack of arc mon by region by eastward with or without subduction of the hypothetical Shatsky \&

These models fail because they ignore many factors and much contrary data, some of
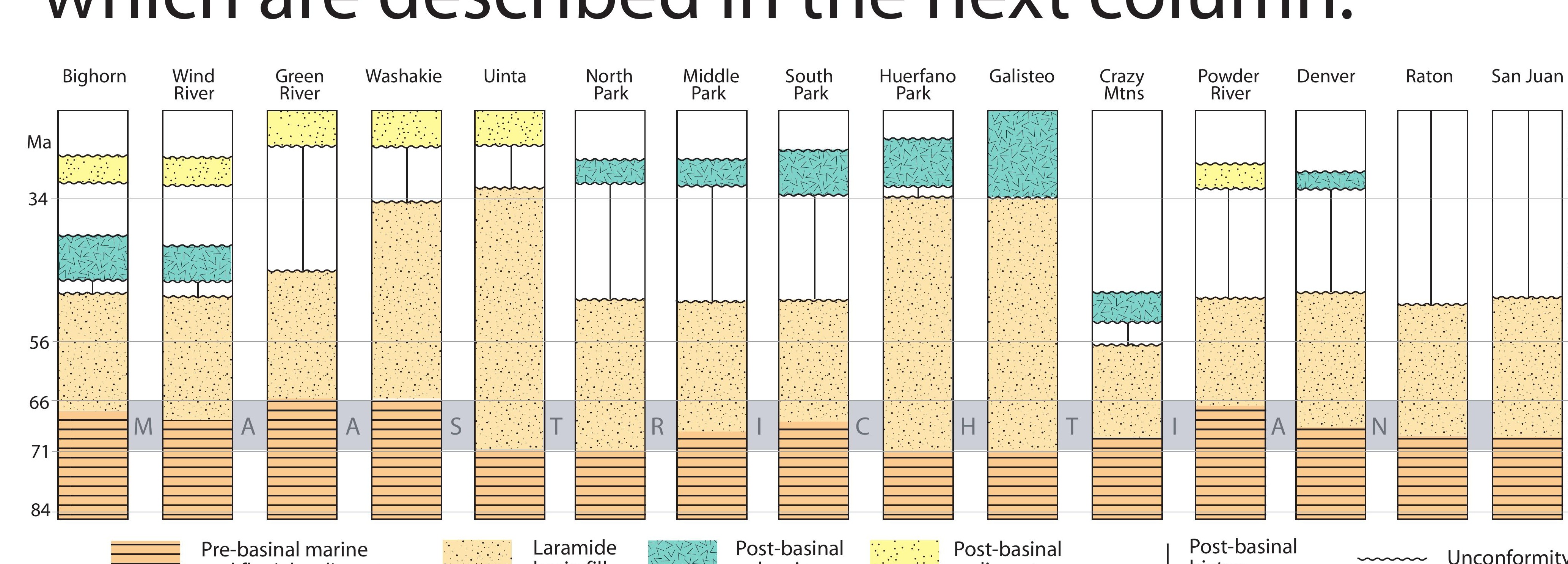

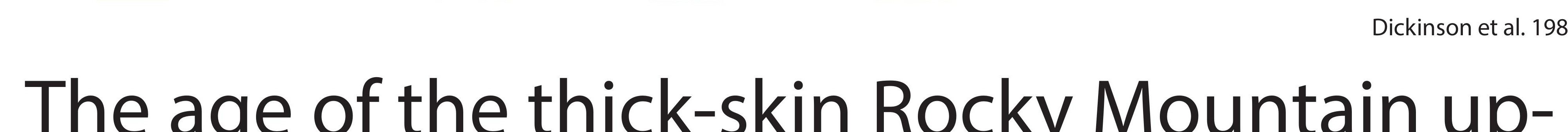
lifts and their adjackst Racky Mountain upIifts and their adjacent basinsis Mad References

References

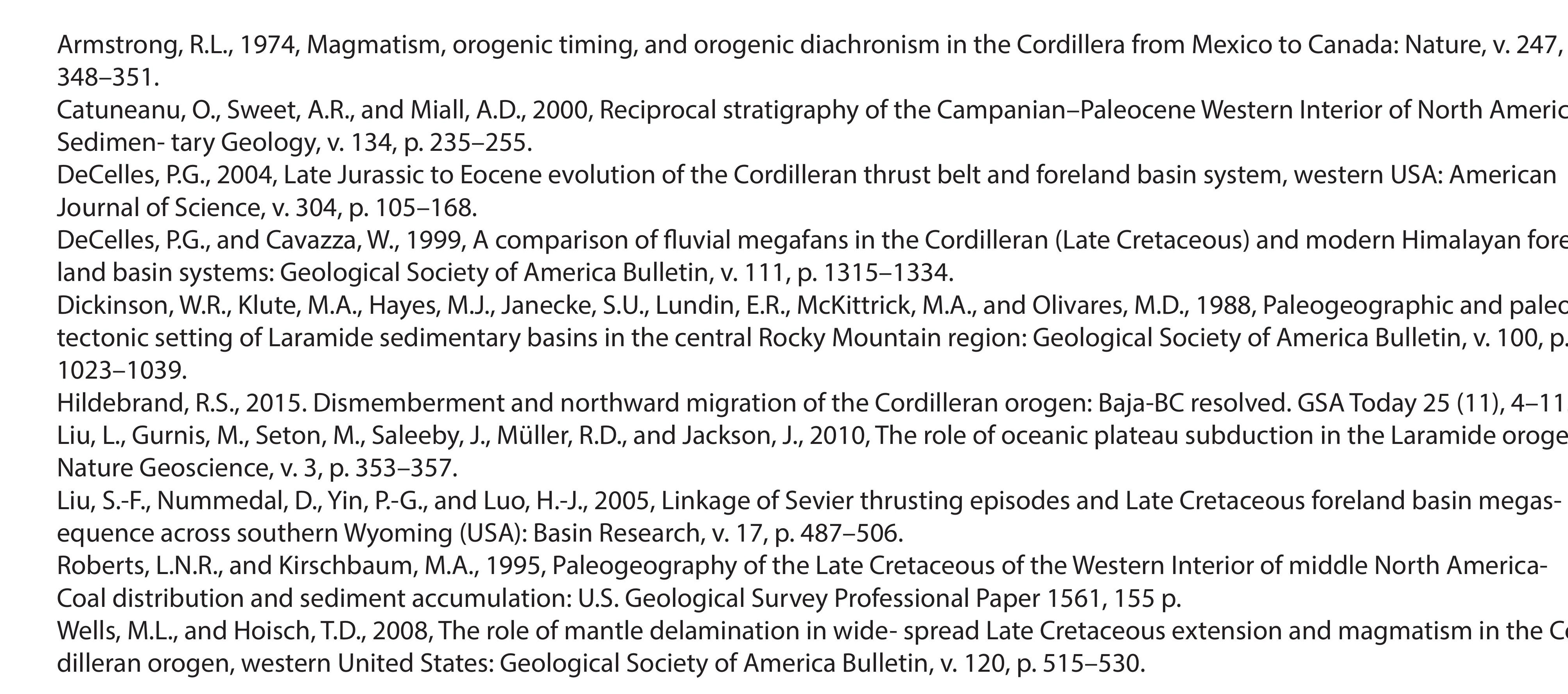

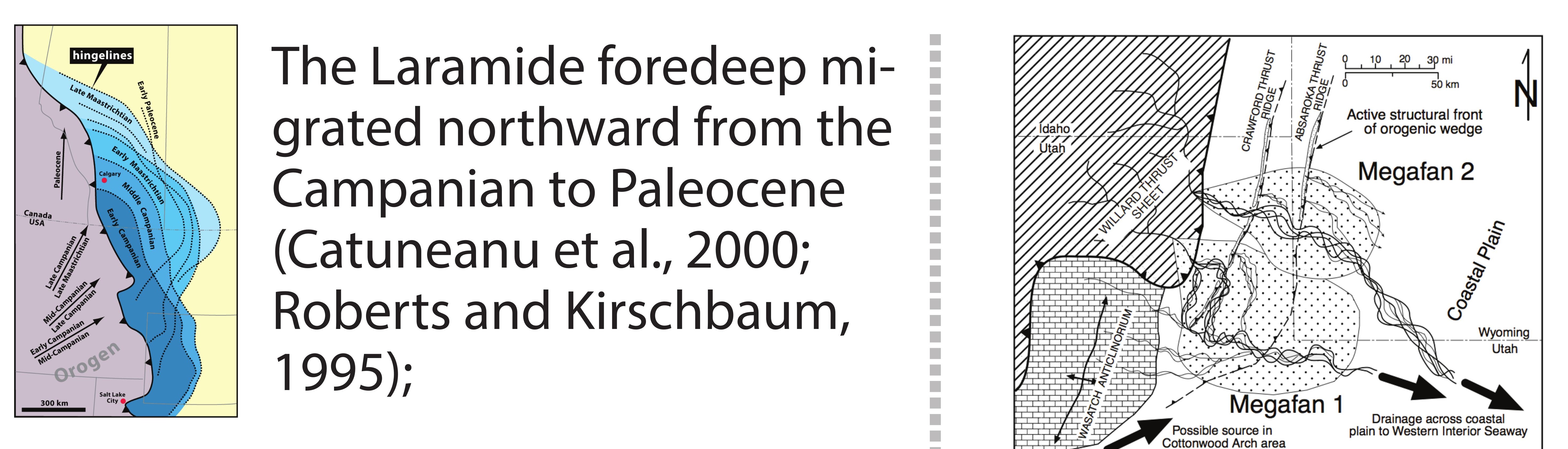

The thrusting in the US $=2 \quad \begin{aligned} & \text { The thrusting in the US } \\ & \text { thin-skinned fold-thrust } \\ & \text { beltwas more orless }\end{aligned}$ belt was more or less coeval with deformation and metamorphism

within the orogenic hinterland, and stopped by the mid-Campanian, when the leading edge the thrust belt was rocks of the adjacent foredeep, buried by conglomerate and gravels fluvial megafans derived from the more interior portions of the thrust wedge (DeCelles and Cavazza, 1999; DeCelles,
2004; Liu et al., 2005).

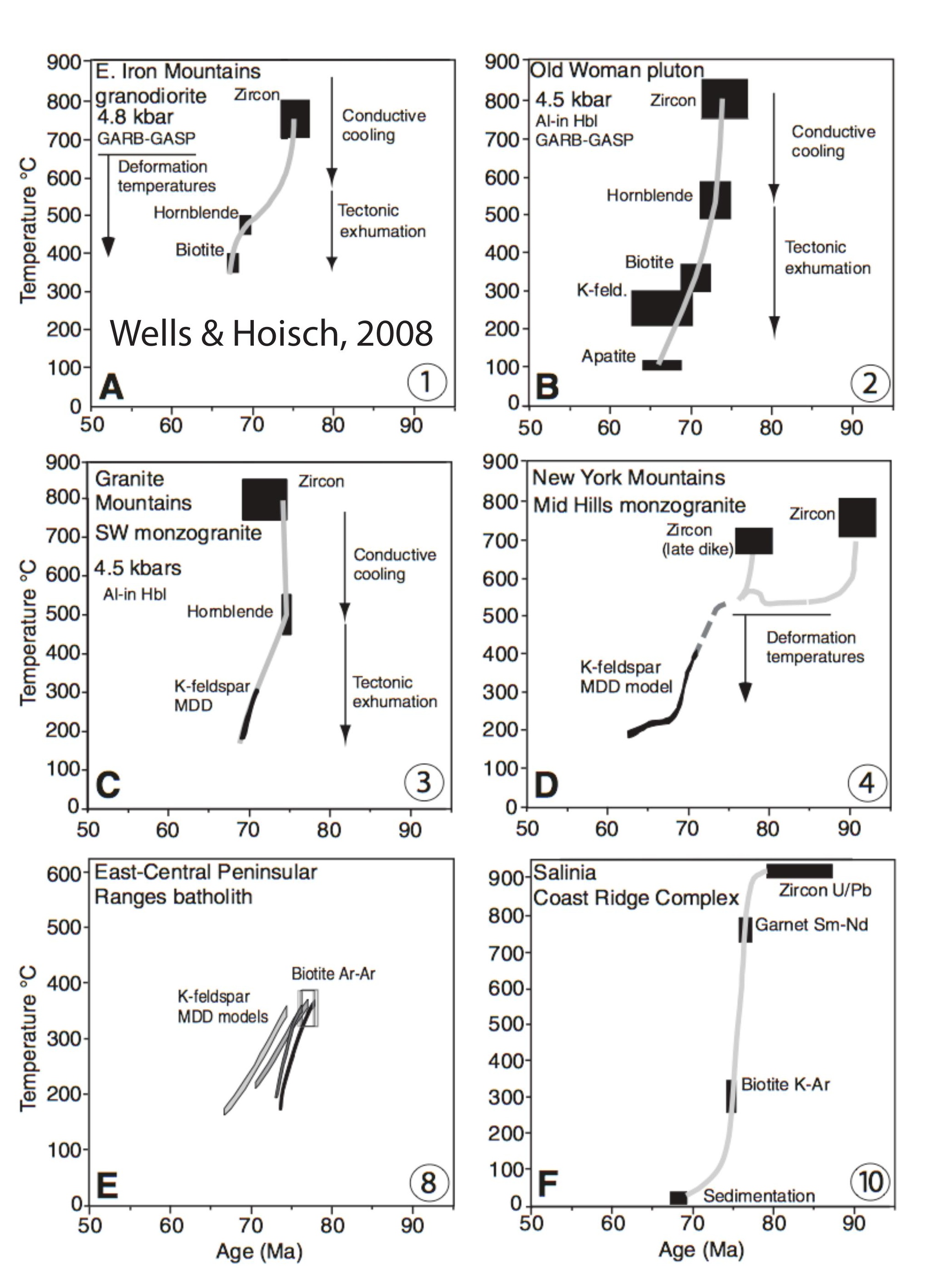

Exhumation in the hinterland started during the Late Campanian when thin
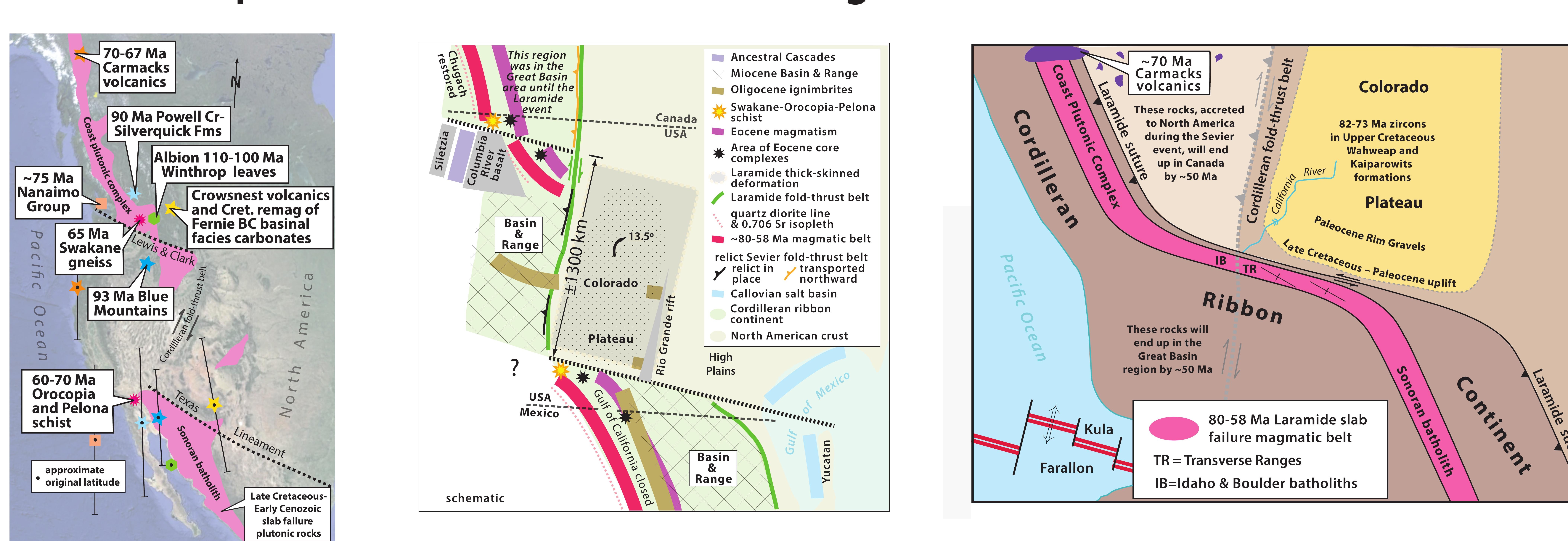

A long-standing problem in Cordilleran geology is the far-sided paleopoles for most regions west of cratonic North America. Hildebrand (2015) used the Lewis \& Clark and Texas lineaments as able strike-slip movement on faults of the fold-thrust belt also re-unites the orogenic hinterland and its swarm of post-collisional slab failure plutons into a continuous band.

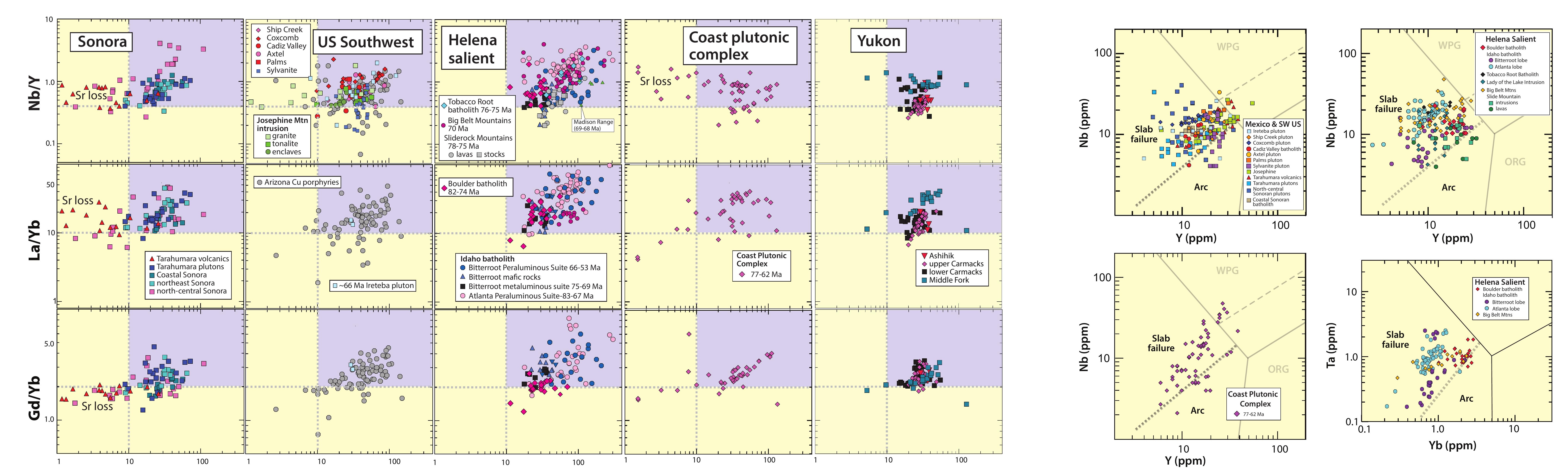

Uppermost Cretaceous to Paleocene plutons have slab failure, not arc, geochemistry consistent with their emplacement during regional exhumation.
Closure of a poorly known basin, which must have been wide enough to have had oceanic belt. Once the slab failed, thrusting ceased slab melts formed, and the pluton-riddled hin- terland was exhumed. Northward migration likely driven by the Kula-Farallon ridge, gener- ated the thick-skin Laramide-type structures and drove the Cordillera northward about $1300 \mathrm{~km}$. Eocene-Miocene arc magmatism formed from N-NE subduction as indicated by the volcanic isochrons across the Great Basin.

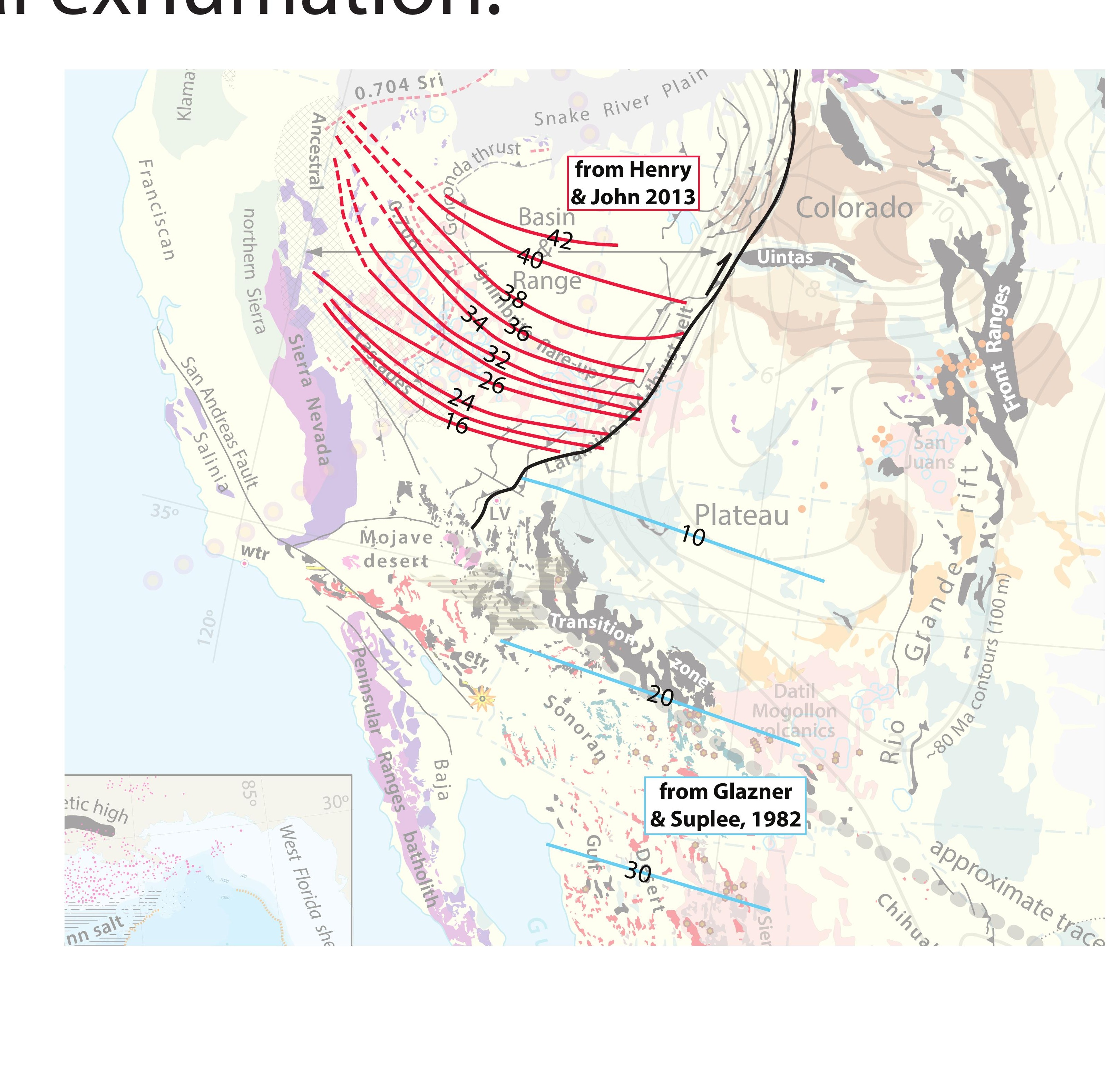

